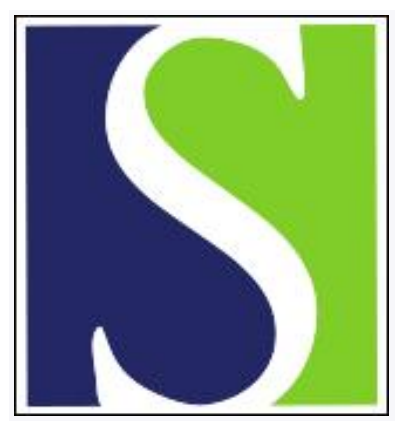

Scand J Work Environ Health 2011;37(3):219-226

https://doi.org/10.5271/sjweh.3134

Published online: 22 Nov 2010, Issue date: May 2011

Low mortality and myocardial infarction incidence among flying personnel during working career and beyond

by Linnersjö A, Brodin L-Å, Andersson C, Alfredsson L, Hammar N

Affiliation: Institute of Environmental Medicine, Unit of Cardiovascular Epidemiology, Karolinska Institutet, S-171 77 Stockholm, Sweden. anette.linnersjo@ki.se

Key terms: aircraft; aviation; commercial aircrew; flying personnel; military personnel; mortality; myocardial infarction; working career

This article in PubMed: www.ncbi.nlm.nih.gov/pubmed/21103803 


\title{
Low mortality and myocardial infarction incidence among flying personnel during working career and beyond
}

\author{
By Anette Linnersjö, MSc, ${ }^{1,2}$ Lars-Åke Brodin, PhD, ,3, 4, 5 Carin Andersson, MSc, ${ }^{5}$ Lars Alfredsson, PhD, ${ }^{1}$ \\ Niklas Hammar, PhD, 6,7
}

\begin{abstract}
Linnersjö A, Brodin L- $\AA$, Andersson C, Alfredsson L, Hammar N. Low mortality and myocardial infarction incidence among flying personnel during working career and beyond. Scand J Work Environ Health. 2011;37(3):219-226. doi:10.5271/sjweh.3134
\end{abstract}

Objective The aim of this study was to evaluate mortality and acute myocardial infarction (AMI) incidence among commercial and military flying personnel in Sweden.

Methods Flying personnel, employed at the Swedish part of Scandinavian Airlines and/or the Swedish Armed Forces at some point between 1957-1994, were included. The cohort was followed regarding mortality and AMI incidence using national registers of hospital discharges and deaths. The observed mortality and AMI incidence was compared with the expected rate in the general Swedish population through standardized mortality ratios (SMR) and standardized incidence ratios (SIR) taking age, gender, and calendar year into account.

Results Swedish flying personnel, except male cabin crew, had a lower-than-expected all-cause mortality (SMR ranging from 0.57 among female cabin crew to 0.79 among navigators and mechanics; male cabin crew 0.89 ) and cardiovascular mortality (SMR from 0.31 among female cabin crew to 0.79 among navigators and mechanics). We observed an elevated mortality in aircraft accidents (SMR ranging from 23.87 among commercial pilots to 165.68 among military pilots). Male cabin attendants had a higher-than-expected mortality for alcohol-related death causes and acquired immunodeficiency syndrome (AIDS). AMI incidence was reduced in all groups and across the lifespan (SIR between 0.13 among female cabin crew and 0.61 among navigators and mechanics).

Conclusions Swedish flying personnel have a low all-cause mortality. This is mostly due to a reduced cardiovascular mortality reflecting a low AMI incidence during the working life as well as after retirement.

Key terms aircraft; aviation; commercial aircrew; military personnel.

Several studies have reported a lower-than-expected cardiovascular mortality among flying personnel compared to the general population (1-9). This has many possible explanations including individual as well as occupation-related factors. When entering the profession, flying personnel in general need to be in good health. This is true for military and commercial pilots, navigators, and flying mechanics and also, to some extent, cabin crew. In Sweden, military flying personnel need to stay in good physical shape throughout their careers to manage the yearly mandatory physical tests
$(10,11)$. Commercial flying personnel also undergo regular medical examinations $(12,13)$. There are several factors in the work environment of flying personnel that may influence the risk of cardiovascular disease. These include exposure to exhaust fumes and irregular working hours (14). In particular, airline personnel may also be exposed to job strain (high psychological demands and low work control) (15) and - for those working on long distance flights - disruptions of the circadian rhythm. Historically, airline personnel were also exposed to environmental tobacco smoke. Before 1997, smoking

1 Unit of Cardiovascular Epidemiology, Institute of Environmental Medicine, Karolinska Institutet, Stockholm, Sweden

2 School of Public Health, Karolinska Institutet, Stockholm, Sweden

3 Division of Medical Engineering, School of Technology and Health, KTH Royal Institute of Technology, Stockholm, Sweden

4 Department of Laboratory Medicine, Karolinska Institutet, Stockholm, Sweden

5 Aleris Aero Medical Centre, Stockholm, Sweden

6 Unit of Epidemiology, Institute of Environmental Medicine, Karolinska Institutet, Stockholm, Sweden

7 AstraZeneca R\&D, Mölndal, Sweden

Correspondence to: Anette Linnersjö, Institute of Environmental Medicine, Unit of Cardiovascular Epidemiology, Karolinska Institutet, Box 210, S-171 77 Stockholm, Sweden. [E-mail: anette.linnersjo@ki.se] 
was allowed in the cabin of SAS aircrafts exposing especially cabin crew, but also pilots to some extent, to environmental tobacco smoke (16). These factors would tend to balance a healthy selection effect into the occupation with regard to cardiovascular risk.

In Sweden, commercial as well as military flying personnel are categorized as high-level non-manual employees (17). This socioeconomic group has been associated with a reduced risk of cardiovascular disease (18). A low mortality from cardiovascular diseases could, at least theoretically, be due to a better survival after acute myocardial infarction (AMI). An increased awareness of symptoms and signs and a greater propensity to seek care leading to an earlier start of treatment could ensure a better survival. From an air safety perspective, it is important to know whether the low cardiovascular mortality reflects a correspondingly low myocardial infarction incidence; from a public health perspective, it is also of interest to see if it lasts even after retirement $(19,20)$. Although several studies have shown a lower cardiovascular mortality among flying personnel as compared to the general population, there are few studies on cardiovascular disease incidence during working life (21-23) but essentially no studies including cardiovascular disease incidence after retirement. Very few studies include both airline and military flying personnel (14). These groups have in some respects a common background in the recruitment into the occupation but, as noted above, differ in several respects with regard to occupational exposures of possible relevance for cardiovascular risk.

The aim of this study was to analyze the mortality pattern among commercial and military flying personnel and investigate the myocardial infarction incidence among these groups in Sweden using national registers of causes of death and AMI. In Sweden, cohorts of military as well as airline personnel have been compiled that can be followed in national registers providing information on AMI incidence.

\section{Methods}

\section{Subjects}

The cohort for this study consisted of (i) male commercial pilots working at Swedish bases of Scandinavian Airlines (SAS), resident in Sweden, and employed anytime between 1957-1994 (N=1478); (ii) cabin attendants from Swedish bases of SAS employed during the same time period (632 male and 2324 female); and (iii) military pilots $(\mathrm{N}=2166)$, navigators, and mechanics $(\mathrm{N}=991)$ recorded in the medical records 1957-1994 in the Aero Medical Centre at Swedish Armed Forces. As there were very few female pilots, navigators, and flying mechanics, this study was restricted to males in these occupations. The compilation of the cohort has been described in earlier studies $(24,25)$. Dates of employment for the airline personnel were collected from archives at SAS. Cause-specific deaths for the cohort were retrieved from the Swedish national causes of death register.

Since 1986, the retirement age for military pilots in Sweden has been 55 years. Prior to 1986, they had flying duty until 50 years of age and then worked with other military duties until 60 years. The retirement age has always been 60 years old for the rest of the military personnel. The retirement age for Swedish SAS pilots and cabin crew is 60 years of age. During earlier years, the cabin crew could start working part-time from 55 years of age. SAS pilots can continue working on short distance flights until 65 years if they wish. Cabin attendants are allowed to continue working until 67 years if they are healthy.

We present results for major causes of deaths including total, cardiovascular disease, cancer, and external causes with aircraft accidents presented separately. In addition, results are presented for alcohol-related deaths and deaths due to acquired immunodeficiency syndrome (AIDS) since these causes have been highlighted in previous papers $(8,26)$. Information on other causes of deaths is available upon request from the authors. Detailed cancer incidence data have been published on these cohorts previously $(24,25)$. The presented causes of deaths were defined as cancer [International Classification of Diseases, 9th revision (ICD-9): 140-208)], cardiovascular disease (ICD-9: 390-416, 420-441, 444, 453), aircraft accidents (ICD-9: E840-E844), external causes except aircraft accidents (ICD-9: E800-E999 except E840E844), AIDS (ICD-9: 279.5-279.6), and alcohol-related deaths (ICD-9: 291, 303, 305.0, 357.5, 535.3, 571).

Incident cases of AMI were identified through the national hospital discharge register and the national causes of death register. AMI incidence was defined as ICD-9 code 410. All hospital discharges with AMI and all deaths due to AMI for the cohort members were extracted from the registers and regarded as the same AMI episode if they occurred within 28 days. The Swedish National Board of Health and Welfare uses this method, which has been evaluated in earlier studies (27).

These Swedish national cause of death and hospital discharge registers cover all deaths among permanent residents of Sweden, irrespective of whether the death occurred in Sweden or abroad, and every hospitalization regarding acute medical cases in Sweden respectively. These registers were linked to the cohort of flying personnel using the personal identification number, unique to every resident of Sweden. The quality of these registers 
is good and linkage can be performed essentially without loss due to the Swedish personal identification numbers (28-31). Only $0.5 \%$ of the deaths in the national cause of death register lacked information on cause. Less than $1 \%$ of hospital discharges in the national hospital discharge register lacked personal identification number and $<1 \%$ lacked main diagnosis. We also obtained information about the mortality and AMI incidence in the general population from these registers. The follow-up period for mortality was 1961-1999 and 1987-1999 for AMI incidence since the Swedish hospital discharge register began national coverage of hospitalizations in 1987. From a register of migration at Statistics Sweden, we recorded all migrations into or out of Sweden by members of the study population during the years 1968-1999.

In the analysis of mortality, the observation period began 1 January 1961, at the time of employment (SAS personnel), date of first medical examination (military personnel), or immigration to Sweden, whichever came last. It ended 31 December 1999, at the time of death, or emigration out of Sweden, whichever came first. In the analysis of AMI incidence, the observation period started on 1 January 1987, at the time of employment (SAS personnel), date of first medical examination (military personnel), or immigration to Sweden, whichever came last. It ended 31 December 1999, at the time of AMI, at time of death, or emigration out of Sweden, whichever came first.

\section{Statistical analysis}

Person years at risk were calculated in 5-year age and calendar intervals using the software package Epicure release 2.10 (Hirosoft International Corp, Seattle, WA, USA). Expected numbers of deaths and incident AMI were calculated using age, gender, and calendar-yearspecific mortality and AMI incidence rates in the Swed- ish population. Standardized mortality ratios (SMR) were calculated dividing observed numbers of deaths by expected numbers using SAS for Windows version 9.1 (SAS Institute, Cary, NC, USA). Standardized incidence ratios (SIR) were calculated correspondingly. Both SMR and SIR were accompanied by $95 \%$ confidence intervals $(95 \% \mathrm{CI})$ assuming that the observed number of cases followed a Poisson distribution. For a direct comparison of AMI incidence between commercial and military pilots, a standardized relative risk (SRR) was calculated by gender using 5 -year age groups.

\section{Results}

The military personnel had a higher inclusion age in the beginning of the study period because, prior to 1968 , the health examinations began when the individual reached 40 years of age (table 1). All groups of flying personnel, except male cabin crew, had a reduced all-cause mortality (figure 1A). Commercial pilots and female cabin crew had about $40 \%$ reduced mortality, and military flying personnel had a $25 \%$ reduction. If we exclude the aircraft accidents from the total mortality, the SMR decreased by an additional $4-15 \%$ in the different flying personnel groups.

Military pilots and female cabin crew had a reduced risk of cancer mortality while the other groups had about the same risk as the population (figure 1B). Mortality from cardiovascular diseases was substantially reduced in all groups (figure $1 \mathrm{C}$ ). It was a $20 \%$ reduction among navigators and mechanics and a 50\% reduction among commercial pilots, military pilots, and male cabin crew. Female cabin crew had a very low cardiovascular mortality (SMR 0.31, 95\% CI 0.09-0.80).

Table 1. Characteristics of the cohort by occupational group. [SAS=Scandinavian Airlines; AMI=acute myocardial infarction.]

\begin{tabular}{|c|c|c|c|c|c|c|c|c|c|c|c|c|}
\hline & \multicolumn{6}{|c|}{ Swedish part of SAS } & \multicolumn{4}{|c|}{ Military } & \multirow{2}{*}{\multicolumn{2}{|c|}{$\frac{\text { Total }}{\text { Flying personnel }}$}} \\
\hline & \multirow{2}{*}{\multicolumn{2}{|c|}{ Pilots }} & \multicolumn{4}{|c|}{ Cabin crew } & \multirow{2}{*}{\multicolumn{2}{|c|}{ Pilots }} & \multirow{2}{*}{\multicolumn{2}{|c|}{$\begin{array}{l}\text { Navigators and } \\
\text { flying mechanics }\end{array}$}} & & \\
\hline & & & \multicolumn{2}{|c|}{ Male } & \multicolumn{2}{|c|}{ Female } & & & & & & \\
\hline & $\mathrm{N}$ & $\%$ & $\mathrm{~N}$ & $\%$ & $\mathrm{~N}$ & $\%$ & $\mathrm{~N}$ & $\%$ & $\mathrm{~N}$ & $\%$ & $\mathrm{~N}$ & $\%$ \\
\hline Individuals & 1478 & 19.5 & 632 & 8.3 & 2324 & 30.6 & 2166 & 28.5 & 991 & 13.1 & 7591 & 100 \\
\hline Deaths & 121 & 8.2 & 61 & 9.7 & 39 & 1.7 & 379 & 17.5 & 185 & 18.7 & 785 & 10.3 \\
\hline Incident cases of AMI a & 30 & 2.0 & 12 & 1.9 & 2 & 0.1 & 101 & 4.7 & 59 & 6.0 & 204 & 2.7 \\
\hline Emigrated out of Sweden & 222 & 15.0 & 95 & 15.0 & 350 & 15.1 & 97 & 4.5 & 31 & 3.1 & 795 & 10.5 \\
\hline Mean years of follow-up b & 21.9 & $\cdot$ & 22.6 & $\cdot$ & 20.2 & $\cdot$ & 23.6 & $\cdot$ & 24.0 & $\cdot$ & 22.2 & $\cdot$ \\
\hline Mean age at inclusion & 30.5 & $\cdot$ & 27.5 & $\cdot$ & 25.5 & $\cdot$ & 33.2 & $\cdot$ & 35.1 & $\cdot$ & 30.1 & $\cdot$ \\
\hline Total person-years & 33127 & 19.2 & 14658 & 8.5 & 48001 & 27.9 & 52141 & 30.3 & 24252 & 14.1 & 172179 & 100 \\
\hline
\end{tabular}

a Inclusion date=date of employment (SAS personnel) or first medical examination (military personnel), 1987, or immigration whichever comes last

b Inclusion date=date of employment (SAS personnel) or first medical examination (military personnel), 1961, or immigration whichever comes last 

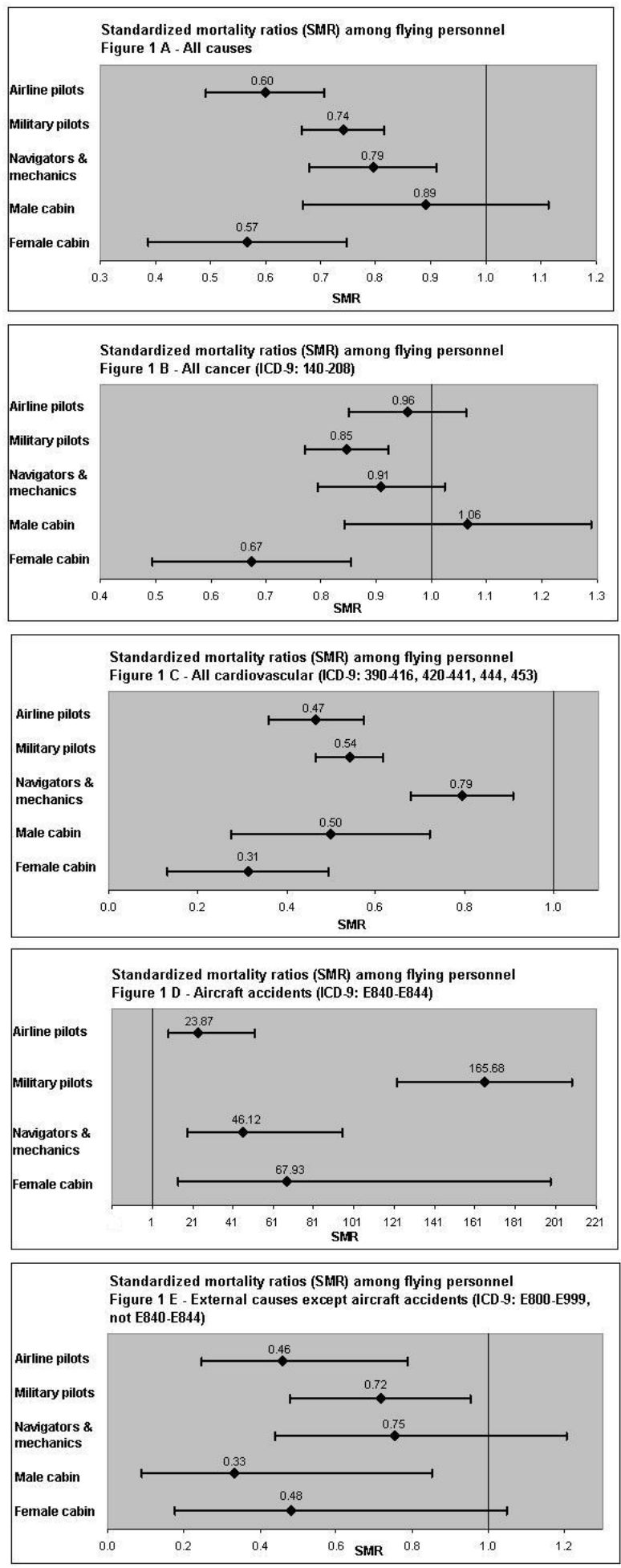

Figure 1. Standardized mortality ratio (SMR) among flying personnel: Figure 1 A-all-cause mortality; figure 1B-all cancer (ICD-9: 140-208); figure $1 \mathrm{C}$ - all cardiovascular disease (ICD-9: 390-416, 420-441, 444, and 453); figure $1 \mathrm{D}$ - aircraft accidents (ICD-9: E840-E844); figure $1 \mathrm{E}$ - external causes except aircraft accidents (ICD-9: E800-E999 not E840-E844).
An excess mortality was found for aircraft accidents in all groups, except male cabin crew with no recorded deaths due to this cause (figure 1D). Mortality due to aircraft accidents was most common among military pilots (SMR 165.68, 95\% CI 122.28-209.07). Commercial pilots had a SMR of 23.87 (95\% CI 8.76-51.94). Navigators and mechanics as well as female cabin crew had a mortality ratio in aircraft accidents in between the pilot groups. All aircraft accidents for cabin crew as well as navigators and mechanics were classified as occupational in the national causes of death register. The corresponding figures were $83 \%$ and $75 \%$ for commercial and military pilots, respectively.

Mortality from external causes, apart from aircraft accidents, was significantly reduced in all groups except navigators and mechanics (figure 1E). Among pilots and cabin crew, it was approximately halved.

Alcohol-related mortality was reduced in all groups except male cabin crew who had a more than doubled mortality compared with the expected rate (SMR 2.66, 95\% CI 1.15-5.23). Male cabin attendants had also an increased AIDS mortality (SMR 47.31, 95\% CI 19.02-97.47).

The reduced total as well as cardiovascular mortality was present over the whole study period with only small fluctuations (not shown). The reduction was found in all age groups except $\geq 80$ years of age for all cardiovascular mortality (table 2). The high mortality due to aircraft accidents mainly existed in lower age groups. Dividing cabin crew by age group resulted in small numbers indicating the same pattern (not shown).

In all occupational groups, the AMI incidence was lower than expected (table 3). Commercial flying personnel had significantly lower SIR than military personnel. Analyses of AMI incidence by time period showed that the incidence reduction was most pronounced in the later years. The risk reduction in AMI incidence was present in all age groups even after retirement.

By calculating a SRR, we made a comparison of the AMI incidence between commercial and military pilots. The SRR was 1.99 (95\% CI 1.11-3.55) for military versus commercial pilots.

\section{Discussion}

Our study confirms the low all-cause and cardiovascular mortality among pilots and female cabin crew and no reduced total mortality among male cabin attendants $(2,8)$. Furthermore, it shows that the low cardiovascular mortality is at least in part explained by a reduced incidence of AMI. Among pilots, a low cardiovascular risk is most likely related to the recruitment of healthy persons into the profession. 
Table 2. All-cause and cardiovascular mortality, and deaths in aircraft accidents 1961-1999 in different age groups among male commercial pilots employeed in the Swedish part of Scandinavian Airlines (SAS) and male military pilots, navigators, and flying mechanics in the Swedish Armed Forces compared with men in Sweden. Standardized mortality ratio (SMR) with 95\% confidence intervals (95\% CI) with consideration to age and time period are given. [Obs=0bserved number of cases; Exp=expected number of cases.]

\begin{tabular}{|c|c|c|c|c|c|c|c|c|c|c|c|c|}
\hline \multirow[t]{2}{*}{ Age groups } & \multicolumn{4}{|c|}{$\begin{array}{c}\text { Commercial pilots } \\
\text { (Swedish part of SAS) }\end{array}$} & \multicolumn{4}{|c|}{ Military pilots } & \multicolumn{4}{|c|}{$\begin{array}{l}\text { Military navigators } \\
\text { and mechanics }\end{array}$} \\
\hline & Obs & Exp & SMR & $95 \% \mathrm{Cl}$ & Obs & Exp & SMR & $95 \% \mathrm{Cl}$ & Obs & Exp & SMR & $95 \% \mathrm{Cl}$ \\
\hline \multicolumn{13}{|l|}{ All causes } \\
\hline $15-29$ & 1 & 2.85 & 0.35 & $0.01-1.96$ & 22 & 3.99 & 5.52 & $3.21-7.82$ & 3 & 1.54 & 1.95 & $0.40-5.70$ \\
\hline 30-39 & 6 & 14.60 & 0.41 & $0.15-0.89$ & 33 & 15.75 & 2.09 & $1.38-2.81$ & 9 & 6.65 & 1.35 & $0.62-2.57$ \\
\hline $40-49$ & 11 & 28.10 & 0.39 & $0.20-0.70$ & 33 & 44.18 & 0.75 & $0.49-1.00$ & 12 & 20.99 & 0.57 & $0.30-1.00$ \\
\hline $50-59$ & 30 & 46.12 & 0.65 & $0.42-0.88$ & 54 & 89.11 & 0.61 & $0.44-0.77$ & 30 & 44.11 & 0.68 & $0.44-0.92$ \\
\hline $60-69$ & 34 & 55.95 & 0.61 & $0.40-0.81$ & 86 & 133.17 & 0.65 & $0.51-0.78$ & 51 & 70.20 & 0.73 & $0.53-0.93$ \\
\hline $70-79$ & 33 & 47.55 & 0.69 & $0.46-0.93$ & 100 & 159.43 & 0.63 & $0.50-0.75$ & 69 & 67.96 & 1.02 & $0.78-1.25$ \\
\hline$\geq 80$ & 6 & 6.69 & 0.90 & $0.33-1.95$ & 51 & 66.00 & 0.77 & $0.56-0.98$ & 11 & 21.34 & 0.52 & $0.26-0.92$ \\
\hline \multicolumn{13}{|c|}{$\begin{array}{l}\text { All cardiovascular } \\
\text { mortality }\end{array}$} \\
\hline $30-39$ & 0 & 1.74 & $\cdot$ & $\cdot$ & 2 & 1.85 & 1.08 & $0.13-3.90$ & 1 & 0.79 & 1.27 & $0.03-7.08$ \\
\hline $40-49$ & 2 & 7.55 & 0.26 & $0.03-0.96$ & 4 & 12.05 & 0.33 & $0.09-0.85$ & 6 & 5.73 & 1.05 & $0.38-2.28$ \\
\hline $50-59$ & 9 & 18.83 & 0.48 & $0.22-0.91$ & 15 & 36.91 & 0.41 & $0.23-0.67$ & 14 & 18.38 & 0.76 & $0.42-1.28$ \\
\hline $60-69$ & 12 & 27.47 & 0.44 & $0.23-0.76$ & 39 & 67.41 & 0.58 & $0.40-0.76$ & 23 & 35.29 & 0.65 & $0.39-0.92$ \\
\hline $70-79$ & 11 & 24.39 & 0.45 & $0.23-0.81$ & 42 & 84.17 & 0.50 & $0.35-0.65$ & 35 & 35.40 & 0.99 & $0.66-1.32$ \\
\hline$\geq 80$ & 5 & 3.57 & 1.40 & $0.45-3.27$ & 27 & 36.02 & 0.75 & $0.47-1.03$ & 6 & 11.52 & 0.52 & $0.19-1.13$ \\
\hline \multicolumn{13}{|c|}{ Aircraft accidents } \\
\hline $15-29$ & 1 & 0.04 & 25.88 & $0.65-144.20$ & 20 & 0.05 & 430.29 & $262.84-664.54$ & 2 & 0.02 & 108.39 & $13.12-391.56$ \\
\hline 30-39 & 3 & 0.09 & 32.29 & $6.66-94.38$ & 24 & 0.09 & 266.38 & $159.81-372.95$ & 3 & 0.04 & 77.90 & $16.07-227.64$ \\
\hline $40-49$ & 0 & 0.07 & & & 10 & 0.10 & 95.36 & $45.73-175.37$ & 1 & 0.05 & 20.58 & $0.51-114.68$ \\
\hline $50-59$ & 2 & 0.04 & 45.75 & $5.54-165.28$ & 2 & 0.08 & 26.15 & $3.16-94.45$ & 1 & 0.04 & 27.94 & $0.70-155.70$ \\
\hline
\end{tabular}

Table 3. Acute myocardial infarction (AMI) incidence (1987-1999) in different age groups and periods among male commercial pilots and cabin crew employed in the Swedish part of Scandinavian Airlines (SAS) as well as male military pilots, navigators, and flying mechanics in the Swedish Armed Forces compared with men and women in Sweden. Standardized incidence ratio (SIR) with 95\% confidence intervals $(95 \% \mathrm{Cl})$ with consideration to age and time period are given. [Obs=0bserved number of cases; Exp=expected number of cases.]

\begin{tabular}{|c|c|c|c|c|c|c|c|c|c|c|c|c|}
\hline & \multicolumn{4}{|c|}{$\begin{array}{c}\text { Commercial pilots } \\
\text { (Swedish part of SAS) }\end{array}$} & \multicolumn{4}{|c|}{ Military pilots } & \multicolumn{4}{|c|}{$\begin{array}{l}\text { Military navigators } \\
\text { and mechanics }\end{array}$} \\
\hline & Obs & Exp & SIR & $95 \% \mathrm{Cl}$ & Obs & Exp & SIR & $95 \% \mathrm{Cl}$ & Obs & Exp & SIR & $95 \% \mathrm{Cl}$ \\
\hline Total AMI & 30 & 88.94 & 0.34 & $0.22-0.46$ & 101 & 201.15 & 0.50 & $0.40-0.60$ & 59 & 97.26 & 0.61 & $0.45-0.76$ \\
\hline \multicolumn{13}{|l|}{ Period } \\
\hline $1987-1993$ & 17 & 43.23 & 0.39 & $0.23-0.63$ & 51 & 102.33 & 0.50 & $0.36-0.64$ & 32 & 48.75 & 0.66 & $0.43-0.88$ \\
\hline 1994-1999 & 13 & 45.71 & 0.28 & $0.15-0.49$ & 50 & 98.83 & 0.51 & $0.37-0.65$ & 27 & 48.51 & 0.56 & $0.35-0.77$ \\
\hline \multicolumn{13}{|l|}{ Age groups } \\
\hline $40-49$ & 1 & 6.22 & 0.16 & $0.004-0.89$ & 3 & 9.17 & 0.33 & $0.07-0.96$ & 3 & 4.94 & 0.61 & $0.13-1.78$ \\
\hline $50-59$ & 4 & 19.56 & 0.20 & $0.06-0.52$ & 15 & 30.68 & 0.49 & $0.27-0.81$ & 4 & 13.18 & 0.30 & $0.08-0.78$ \\
\hline $60-69$ & 10 & 31.05 & 0.32 & $0.15-0.59$ & 32 & 55.00 & 0.58 & $0.38-0.78$ & 26 & 34.57 & 0.75 & $0.46-1.04$ \\
\hline $70-79$ & 13 & 28.23 & 0.46 & $0.25-0.79$ & 37 & 79.43 & 0.47 & $0.32-0.62$ & 22 & 35.47 & 0.62 & $0.36-0.88$ \\
\hline \multirow[t]{2}{*}{$\geq 80$} & 2 & 2.88 & 0.69 & $0.08-2.51$ & 14 & 25.99 & 0.54 & $0.29-0.90$ & 4 & 8.68 & 0.46 & $0.13-1.18$ \\
\hline & \multicolumn{4}{|c|}{$\begin{array}{c}\text { Male cabin crew } \\
\text { (Swedish part of SAS) }\end{array}$} & \multicolumn{4}{|c|}{$\begin{array}{c}\text { Female cabin crew } \\
\text { (Swedish part of SAS) }\end{array}$} & & & & \\
\hline Total AMI & 12 & 30.51 & 0.39 & $0.20-0.69$ & 2 & 15.79 & 0.13 & $0.02-0.46$ & & & & \\
\hline \multicolumn{13}{|l|}{ Period } \\
\hline $1987-1993$ & 7 & 14.22 & 0.50 & $0.20-1.02$ & 1 & 5.92 & 0.17 & $0.004-0.94$ & & & & \\
\hline 1994-1999 & 5 & 16.30 & 0.25 & $0.07-0.64$ & 1 & 9.88 & 0.10 & $0.003-0.56$ & & & & \\
\hline \multicolumn{13}{|l|}{ Age groups } \\
\hline $50-59$ & 5 & 8.16 & 0.61 & $0.20-1.43$ & 1 & 4.44 & 0.22 & $0.01-1.25$ & & & & \\
\hline $60-69$ & 5 & 12.12 & 0.41 & $0.13-0.96$ & 1 & 5.03 & 0.20 & $0.005-1.11$ & & & & \\
\hline $70-79$ & 1 & 6.04 & 0.17 & $0.004-0.92$ & 0 & 2.33 & . & . & & & & \\
\hline$\geq 80$ & 1 & 1.08 & 0.93 & $0.02-5.16$ & 0 & 0.09 & . & . & & & & \\
\hline
\end{tabular}


In addition, pilots go through regular medical examinations covering risk factors for cardiovascular diseases among other things. The yearly demand for physical fitness at work and long working time spent doing physical exercise among military flying personnel probably also contributes to a low AMI incidence even after retirement. Exposure to occupational risk factors (eg, job strain, shift work, and exhaust fumes) among flying personnel would tend to increase the risk of AMI, but in spite of this the risk is low. The internal comparison within the cohort showed a higher AMI incidence among military compared to commercial pilots aged $<70$ years. In the absence of information on individual and occupational cardiovascular risk factors, it is not possible to determine the causes of this difference.

There is probably a low prevalence of smoking in this cohort since they had a low lung cancer incidence $(24,25)$; a low smoking prevalence was found in other flying cohorts $(32,33)$. This tends to reduce the AMI incidence. The trend in AMI incidence has been decreasing in Sweden during the study period (34), which combined with lower relative risks over time for flying personnel - would mean a greater reduction of the AMI incidence among flying personnel than among the general population.

It is an important new finding that cabin crew have a low AMI incidence. Cabin crew have to fulfill some demands regarding height and weight as well as being in good physical and mental shape. This means that the obese and overweight will be underrepresented in this group and that possibly a healthier lifestyle in general is promoted. This may have had a favorable influence on mortality and AMI incidence (35). The male cabin crew did not have an improved all-cause mortality in part due to an increased mortality in AIDS and alcohol-related causes of deaths probably related to lifestyle.

The regular medical health examinations mandatory for flying personnel may result in a higher awareness of signs and symptoms of cardiovascular disease, but can also give a sense of increased control of one's health (36). These examinations also give the possibility to discover health problems early and potentially reduce cardiovascular mortality because of earlier detection of risk factors and a greater propensity to seek medical care when cardiac symptoms occur.

The strong selection into the cohort as well as the fact that healthy people are more likely to stay in the occupation results in a healthy worker effect $(37,38)$. One strength of this study is that we follow the flying personnel in national cause of death and hospital discharge registers irrespective of whether they still are working in the occupation or not. We observed large reductions in mortality lasting even after retirement which may suggest that the reduced mortality is not only explained by the healthy worker effect. A similar finding was seen among American pilots (7). In the beginning of their careers, some of the commercial pilots were military pilots. We placed the pilots in the group where they had worked the longest part of their career.

Socioeconomic factors may also have contributed to the low mortality among flying personnel. If we could compare with people from the same social class, the SMR and SIR would probably have been higher (ie, closer to unity). This was the case in an investigation of Swedish physicians (39).

Military pilots, navigators, and mechanics recorded in the medical records 1957-1994 in the Swedish Armed Forces' Aero Medical Centre were included in the study. During 1957-1967, the first medical examination was done at 40 years of age; since 1968, the medical examinations start when the individual is 25 years. In the beginning of the inclusion period, military flying personnel who quit or died before they were 40 were not included in the cohort. This means that we probably omitted some aircraft accidents in the 1960s.

Another strength of this study is that there was essentially no loss of deaths and diagnosed AMI during the follow-up among subjects residing in Sweden due to the excellent coverage of the Swedish national cause of death, population, and hospital discharge registers (28-31). There was a fairly extensive migration out of Sweden in the commercial airline cohorts $(15 \%)$. Unless the migrants represented a less healthy part of the cohort, migration out of Sweden is not a likely explanation for the low observed mortality in these cohorts.

In conclusion, findings from this cohort of Swedish flying personnel confirm the low overall and cardiovascular mortality in these occupational groups. Furthermore, it shows that flying personnel have a low AMI incidence that stays low even after retirement. Although workforce selection most likely is of importance for these findings, our findings suggest that cardiovascular morbidity and mortality can be substantially reduced under specific circumstances and in specific settings.

\section{Acknowledgements}

This work was supported by the Stockholm County Council, the Karolinska Institutet, the Claus Groschinsky Foundation, and the Swedish Council for Work Life Research [grant numbers 2001-0198 and 1997-1128]. The study was carried out on the initiative of the late Harald Eliasch, MD, PhD, Aero Medical Centre, Swedish Armed Forces, and SAS. We are grateful to people at SAS and Aleris Aero Medical Centre who helped us with data collection and other aspects of the study. This work complies with the Declaration of Helsinki and has been evaluated and approved by the Ethical Commit- 
tee of Karolinska Institutet [diary number 99-391]. No conflict of interest is declared.

\section{References}

1. Band PR, Le ND, Fang R, Deschamps M, Coldman AJ, Gallagher RP, et al. Cohort study of Air Canada pilots: mortality, cancer incidence, and leukemia risk. Am J Epidemiol. 1996;143(2):137-43.

2. Blettner M, Zeeb H, Auvinen A, Ballard TJ, Caldora M, Eliasch $\mathrm{H}$, et al. Mortality from cancer and other causes among male commercial cockpit crew in Europe. Int J Cancer. 2003;106(6):946-52. doi:10.1002/ijc.11328.

3. Haldorsen T, Reitan JB, Tveten U. Aircraft accidents and other causes of death among Norwegian commercial pilots. Aviat Space Environ Med. 2002;73(6):587-92.

4. Irvine D, Davies DM. British Airways flightdeck mortality study, 1950-1992. Aviat Space Environ Med. 1999;70(6):548-55.

5. Kaji M, Tango T, Asukata I, Tajima N, Yamamoto K, Yamamoto $\mathrm{Y}$, et al. Mortality experience of cockpit crewmembers from Japan Airlines. Aviat Space Environ Med. 1993;64(8):748-50.

6. MacIntyre NR, Mitchell RE, Oberman A, Harlan WR, Graybiel A, Johnson E. Longevity in military pilots: 37-year followup of the Navy's "1000 aviators". Aviat Space Environ Med. 1978;49(9):1120-2.

7. Qiang Y, Baker SP, Rebok GW, McCarthy ML, Li G. Mortality risk in a birth cohort of commuter air carrier and air taxi pilots. J Occup Environ Med. 2003;45(12):1297-302. doi:10.1097/01.jom.0000099985.06466.fc.

8. Zeeb H, Blettner M, Langner I, Hammer GP, Ballard TJ, Santaquilani M, et al. Mortality from cancer and other causes among commercial cabin attendants in Europe: a collaborative cohort study in eight countries. Am J Epidemiol. 2003;158(1):35-46. doi:10.1093/aje/kwg107.

9. Zeeb H, Langner I, Blettner M. Cardiovascular mortality of cockpit crew in Germany: cohort study. Z Kardiol. 2003;92(6):483-9.

10. Forsvarsmakten.se (Internet). Försvarsmakten [Swedish Armed Forces]. Krav för att bli stridspilot [Demands to become a fighter pilot]. (Cited 2010 July 29). Available at: http://www.forsvarsmakten.se/sv/Rekrytering/Bli-officer/ Funktioner/Luftstrid/Stridspilot/

11. Fhs.se (Internet). Försvarshögskolan [National Defence College]. Tillämpning av Försvarsmaktens baskrav fysisk prestationsförmåga för flygande personal. Bilaga 4 till Försvarshögskolans antagningsordning. Kapitel 5 och 10 [Application of the basic demands for physical capacity among flying personnel in the Swedish Armed Forces. Appendix 4 to the admission regulations from the Swedish National Defence College. Chapter 5 and 10]. (Cited 2010 July 29). Available at: http://www.fhs.se/upload/Utbildning/Dokument/ Bilaga\%204.pdf

12. Aleris.se (Internet). Aleris Flyg- och Dykmedicin. Om Aleris
Flyg- och Dykmedicin [Aleris Aero Medical Centre. About Aleris Aero Medical Centre]. (Cited 2010 July 29). Available at: http://www.aleris.se/Sverige/Sjukvard/Diagnostik/ Aleris-Flyg---och-Dykmedicin/Om-Aleris-Flyg--ochDykmedicin/.

13. SAShms.com (Internet). Scandinavian Airlines - Hälsa, miljö och säkerhet. SAS Företagshälsovård; Medicinsk service [Scandinavian Airlines - Health, environment and security. SAS Occupational health service; Medical service]. (Cited 2010 July 29). Available at: http://www.sashms.com/

14. Boice JD Jr, Blettner M, Auvinen A. Epidemiologic studies of pilots and aircrew. Health Phys. 2000;79(5):576-84. doi:10.1097/00004032-200011000-00016.

15. Wahlstedt K, Lindgren T, Norbäck D, Wieslander G, Runeson R. Psychosocial Work Environment and Medical Symptoms Among Swedish Commercial Airline Cabin Crew. Am J Ind Med. 2010;53(7):716-23.

16. Lindgren T. Cabin air quality in commercial aircraft Exposure, symptoms and signs. Thesis. Acta Universitatis Upsaliensis, Uppsala, Sweden: Uppsala University, 2003. (Cited 2010 July 29). Available at: http://www.dissertations. se/dissertation/d7fd99e5d9/.

17. SCB.se (Internet). Statistics Sweden (SCB). Alfabetisk förteckning över yrkesbenämningar klassificerade enligt Socioekonomisk indelning (SEI). Version 2010-02-01 (ersätter tidigare versioner) [Alphabetical list of occupations classified according to socioeconomic grouping. Version 2010-02-01 (replaces earlier versions)]. (Cited 2010 July 29). Available at: http://www.scb.se/Grupp/Hitta_statistik/Forsta_Statistik/ Klassifikationer/_Dokument/SEI_webb.pdf

18. Rosengren A, Wedel H, Wilhelmsen L. Coronary heart disease and mortality in middle aged men from different occupational classes in Sweden. BMJ. 1988;297(6662):1497-500. doi:10.1136/bmj.297.6662.1497.

19. Pocock SJ, Shaper AG, Phillips AN, Walker M. Prediction of men at high risk of heart attack and its relevance to pilots. Eur Heart J. 1988;9 Suppl G:25-30.

20. Tunstall-Pedoe H. Risk of a coronary heart attack in the normal population and how it might be modified in flyers. Eur Heart J. 1984;5 Suppl A:43-9.

21. Hoiberg A. Cardiovascular disease among U.S. Navy pilots. Aviat Space Environ Med. 1985;56(5):397-402.

22. Hoiberg A, Blood C. Age-specific morbidity among Navy pilots. Aviat Space Environ Med. 1983;54(10):912-8.

23. Qiang Y, Li G, Rebok GW, Baker SP. Body mass index and cardiovascular disease in a birth cohort of commuter air carrier and air taxi pilots. Ann Epidemiol. 2005;15(4):247-52. doi:10.1016/j.annepidem.2004.08.002.

24. Hammar N, Linnersjö A, Alfredsson L, Dammström BG, Johansson M, Eliasch H. Cancer incidence in commercial and military pilots in Sweden 1961-1996. Aviat Space Environ Med. 2002;73(1):2-7

25. Linnersjö A, Hammar N, Dammström BG, Johansson $\mathrm{M}$, Eliasch $\mathrm{H}$. Cancer incidence in commercial cabin crew: experience from Sweden. Occup Environ Med. 2003;60(11):810-4. doi:10.1136/oem.60.11.810. 
26. Haldorsen T, Reitan J B, Tveten U. Cancer incidence among Norwegian commercial cabin attendants. Int $\mathrm{J}$ Epidemiol. 2001;30(4):825-30. doi:10.1093/ije/30.4.825.

27. Hammar N, Alfredsson L, Rosen M, Spetz CL, Kahan T, Ysberg AS. A national record linkage to study acute myocardial infarction incidence and case fatality in Sweden. Int J Epidemiol. 2001 Oct;30 Suppl 1:S30-4.

28. Socialstyrelsen.se (Internet). Stockholm: Socialstyrelsen [Swedish National Board of Health and Welfare]. Värdering av diagnoskvaliteten för akut hjärtinfarkt i patientregistret 1987 och 1995. Epidemiologiskt Centrum, Socialstyrelsen, April 2000 [Evaluation of diagnose quality for acute myocardial infarction in the hospital discharge register 1987 and 1995. Centre for Epidemiology, Swedish National Board of Heath and Welfare, April 2000]. (Cited 2010 July 29). Available at: http://www.socialstyrelsen.se/Lists/Artikelkatalog/ Attachments/17891/2000-0-100.pdf

29. de Faire U, Friberg L, Lorich U, Lundman T. A validation of cause-of-death certification in 1,156 deaths. Acta Med Scand. 1976;200(3):223-8.

30. Socialstyrelsen.se (Internet). Stockholm: Socialstyrelsen [Swedish National Board of Health and Welfare] Bortfall och kvalitet $\mathrm{i}$ dödsorsaksregistret [Drop-out rate and quality of data in the national cause of death register]. (Cited 2010 July 29). Available from: http://www.socialstyrelsen.se/register/ dodsorsaksregistret/bortfallochkvalitet.

31. Socialstyrelsen.se (Internet). Stockholm: Socialstyrelsen [Swedish National Board of Health and Welfare]. Bortfall och kvalitet i patientregistret [Drop-out rate and quality of data in the national hospital discharge register]. (Cited 2010 July 29). Available at: http://www.socialstyrelsen.se/register/ halsodataregister/patientregistret/bortfallochkvalitet (Swedish) and http://www.socialstyrelsen.se/register/ halsodataregister/patientregistret/inenglish.

32. Nicholas JS, Butler GC, Lackland DT, Tessier GS, Mohr LC, Jr., Hoel DG. Health among commercial pilots. Aviat Space Environ Med. 2001;72(9):821-6.
33. Pizzi C, Evans SA, De Stavola BL, Evans A, Clemens F, Silva Idos S. Lifestyle of UK commercial aircrews relative to air traffic controllers and the general population. Aviat Space Environ Med. 2008;79(10):964-74. doi:10.3357/ ASEM.2315.2008.

34. Rosen M, Alfredsson L, Hammar N, Kahan T, Spetz CL, Ysberg AS. Attack rate, mortality and case fatality for acute myocardial infarction in Sweden during 198795. Results from the national AMI register in Sweden. J Intern Med. 2000;248(2):159-64. doi:10.1046/j.13652796.2000.00716.x.

35. Cameron AJ, Dunstan DW, Owen N, Zimmet PZ, Barr EL, Tonkin AM, et al. Health and mortality consequences of abdominal obesity: evidence from the AusDiab study. Med J Aust. 2009;191(4):202-8.

36. Boulware LE, Marinopoulos S, Phillips KA, Hwang CW, Maynor K, Merenstein D, et al. Systematic review: the value of the periodic health evaluation. Ann Intern Med. 2007;146(4):289-300.

37. Baillargeon J. Characteristics of the healthy worker effect. Occup Med. 2001;16(2):359-66.

38. Fox AJ, Collier PF. Low mortality rates in industrial cohort studies due to selection for work and survival in the industry. Br J Prev Soc Med. 1976;30(4):225-30.

39. Gustavsson P, Jakobsson K, Hammar N. Hjärtinfarkt bland manliga och kvinnliga läkare i Stockholm 1977-1996 [Acute myocardial infarction among male and female physicians in Stockholm 1977-1996]. Report No: 2003:6 from Department of Occupational and Environmental medicine. (Cited 2010 July 29). Available from http://www.folkhalsoguiden. se/upload/Arbetsliv/Arbetsliv\%20-\%20rapporter/ $\mathrm{Hj} \%$ c3\%a4rtinfarkt\%20bland \%20manliga\%20och\%20 kvinnliga $\% 201 \%$ c3\%a4kare $\% 20 \mathrm{i} \% 20$ Stockholm $\% 20$ (2003_6).pdf

Received for publication: 19 January 2010 